\title{
Implementation of the online learning platforms in the training companies
}

\author{
O.V. Rostova \\ Associate Professor at the Graduate \\ School of Management and Business \\ Peter the Great St. Petersburg Polytechnic \\ University \\ Saint-Petersburg, Russia \\ o.2908@mail.ru \\ M.S.Zharova \\ Business Analyst of Exploration and \\ Production Systems Directorate \\ Ltd «ITSK» \\ Saint-Petersburg, Russia \\ 0000-0002-0902-520X
}

\begin{abstract}
The article is devoted to the problem of effective implementation of online learning platforms by training companies. The use of e-learning systems in the educational process at this stage is one of the main trends. Despite the fact that the methodological aspects of this form of training are widely covered in the literature, however, the problems associated with the mechanism of implementation of online learning platforms in the educational process of training companies are insufficiently developed. The presented method allows solving the problem of organizational and cost-effective implementation of the online learning platform in the training company.
\end{abstract}

Keywords: online learning platform, training companies, business-processes building, implementation stages, functional requirements, cost-effectiveness of implementation

\section{INTRODUCTION}

The development of information technologies has led to a significant simplification of access to any necessary information and a change in the approach to doing business, as a result, the idea of what should be a specialist in a particular area has significantly changed. The number of required competencies has increased significantly and continues to grow. This trend creates the need for constant acquisition of new knowledge. Competences can be raised in various ways: attending trainings, specialized courses, obtaining additional higher education, etc. But special attention today deserves knowledge through online learning [7]. According to the study of the open portal Openbusiness by 2018 , the audience of online students in Russia has reached 7 million people a year, with the largest part of the popular courses are paid training programs [11]. Of course, this is due to many factors, such as lower cost of courses compared to full-time classes, the geographical aspect (the inability to be physically present at the venue of full-time courses) and others. All of these is a signal to the use of online training in companies.

Currently, many projects are being created in Saint Petersburg, designed to bring business education to a new level [14]. In these projects, the challenge is focused on development of staff competencies, essential for real employers, necessary to the actual business needs through training programs aimed at comprehensive development of the required skills [5]. Business training is a process that affects all aspects of the organization and requires a systematic approach. Corporate trainings are aimed at developing certain skills of the company's personnel to successfully perform business tasks, improve the efficiency of production and commercial activities of specialists, improve management interactions between managers and subordinates, and between managers of equal status. For training companies, an important aspect is both the content of the training and the form of presentation. It is very important that customers seek knowledge using modern approaches and tools. However, training companies face a number of problems in the implementation of online training, as a result of which the use of new technologies is not effective enough [10]. The purpose of this study was to substantiate the feasibility of using and determine the stages of implementation of the online learning platform in the training company.

\section{MATERIALS AND METHODS}

The project of implementation of the online learning system was carried out using a cascade model of project management. To ensure the management and achievement of IT-project results all project activity is divided into a sequence of stages that constitute the life cycle of the project. It makes possible to terminate the project at any stage if its further implementation is deemed inappropriate.

During the implementation of the e-learning program, 6 stages were identified, which are shown in figure 1.

1) Research. Includes a detailed study of the subject area of the problem. Examines current business processes, as well as the necessary changes for the implementation of information systems and e-learning platform. It also considers the organizational structure of the company and possible changes with the further implementation of the software. The duration depends on the functionality of the created system and the software product on which it is created. 


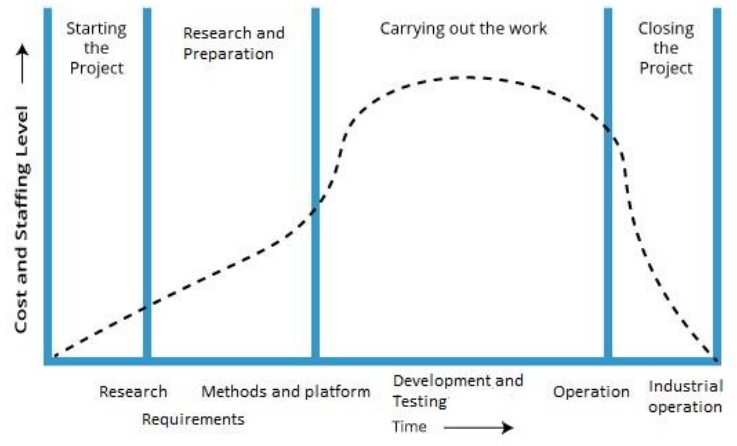

Fig. 1. E - learning program implementation process in the training company

2) Formation of requirements. This stage includes a detailed description of all requirements, both functional and non-functional.

3) Choice of development methods and platform selection. This stage is a detailed analysis of all possible ways to develop the platform, as well as the choice of the supplier of the finished standard solution (when choosing this method of implementation).

4) Testing. At this stage, a demonstration example is prepared, text data is entered, calculation algorithms are checked and errors are corrected (if they were found).

5) Operation. At this stage, work with real data is already in order to identify the current shortcomings of the system, as well as to analyze the effectiveness of the implementation. This stage is especially important for the Analytics and marketing Department to identify the most and least attractive products, time of visit and other key quality indicators.

6) Industrial operation. This stage involves the complete transition of the organization to the use of a new software product, the rejection of any other methods of work beyond the scope of this system. During the stage, its own technical support service of the implemented system is organized or these services are provided by other organizations.

The proposed approach was used in the implementation of the online learning platform in the training company "Vek biznesa", which provides comprehensive training for corporate clients across Russia and the CIS.

\section{RESULTS}

The object of the study was the company "Vek biznesa" that provides training services in various fields of psychology, business and business communications. The organization is constantly expanding the range of services provided, however, the rapidly growing number of competitors in the dynamically developing market creates a number of difficulties in the implementation of the strategy. The existing business model of the company was focused on working with corporate clients, namely with companies that are legal entities. This model was chosen initially due to the presence of an extensive database of contacts of potential customers among the companies of St. Petersburg and Russia as a whole. The company's activities were aimed at the development of the corporate block. Having increased the client portfolio, the organization faced the problem of lack of internal resources. The organization was faced with the question of increasing the coaching staff and at the same time there was a risk of reducing the quality of the services provided. The main difficulty was to reach the audience from the new segments. The company has a need to introduce a platform for online learning, which can lead to the expansion of the range of consumers.

At the first stage, a survey of the company, analysis of current business processes, as well as diagrams of business processes related to the work in the e-learning system were conducted. As an example, Figure 2 shows a diagram of the process "Processing User Requests". This model fully

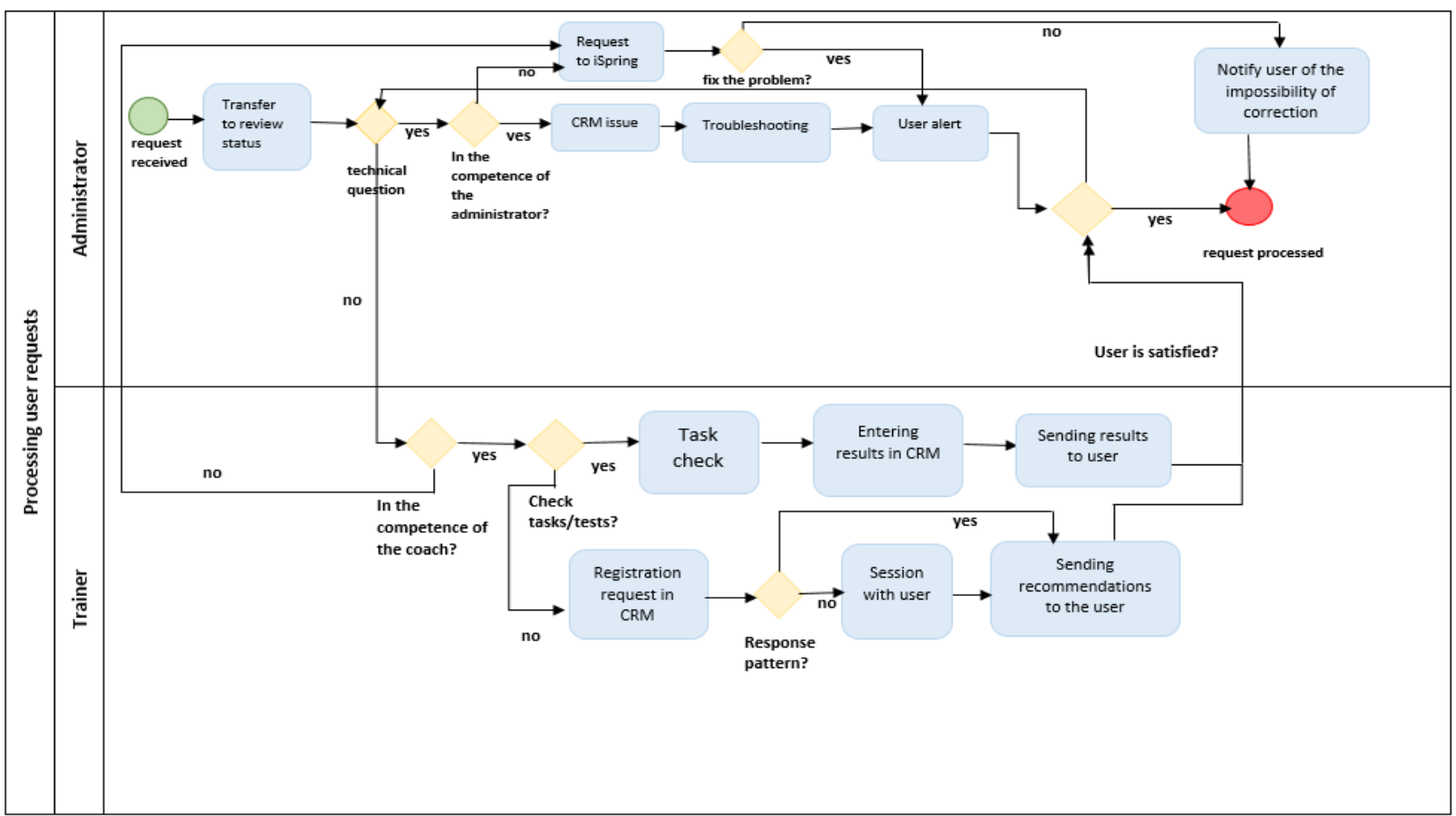

Fig. 2. Process diagram «Processing user request» 
discloses the concept of "user request", while helping to establish the most rapid work with the user to achieve the most satisfaction from his part. This concept, taking into account the specifics of the company, includes not only technical problems, but also tasks sent by the user for verification, as well as questions of different nature addressed to coaches. In such questions, the coach should hold a session to answer all the questions from the students, and then provide the user with the results of a virtual conversation. At the same time, an important part of the model is the entry of all applications into the AmoCrm system, since the processing of requests is certainly taken into account when calculating employee bonuses.

The diagram of the "Registration for training" processes is shown in figure 3 . It reflects all the necessary steps in the initial application for participation in the training of the user. The need for prescribing all processes and their step-by-step follow-up is explained by the fact that when the initial application is submitted by the user, it is necessary to perform all actions as soon as possible, until he has no desire to participate. Lack of knowledge about the sequence of actions can lead to process inhibition and refusal from participation or lack of activity of the user. In addition, users are provided with a primary assessment, which is the author's development of the company's trainers and such a long process of user verification is the primary barrier to competitive intelligence.

Further, the requirements for the content of the future system were formulated, in particular, relating to both the user interface and the system and functional component of the platform (Table.1).

\begin{tabular}{|l|l|}
\multicolumn{1}{c|}{ TABLE I. DESCRIPTION OF REQUIREMENTS } \\
\hline \multicolumn{1}{|c|}{ Level } & \multicolumn{1}{c|}{ Requirement } \\
\hline $\begin{array}{l}\text { Business } \\
\text { requirements }\end{array}$ & $\begin{array}{l}\text { - increase the flow of customers; } \\
\text { entering new market segments; }\end{array}$ \\
\hline Business rules & $\begin{array}{l}\text { - GOST ISO 9001- 2015 Quality management } \\
\text { system. }\end{array}$ \\
\hline
\end{tabular}

\begin{tabular}{|c|c|}
\hline Level & Requirement \\
\hline Restrictions & $\begin{array}{l}\text { - current legislation; } \\
\text { - qualification of the company's divisions; } \\
\text { - cost is not higher than } 300,000 \text { rubles; } \\
\text { - payback period - } 3 \text { months. }\end{array}$ \\
\hline $\begin{array}{l}\text { Functional } \\
\text { requirements }\end{array}$ & $\begin{array}{l}\text { - ability to download materials of various formats } \\
\text { (documents, presentations, videos, etc.); } \\
\text { - simultaneous access to different training programs; } \\
\text { - time limit for courses; } \\
\text { - ability to control from any device for any } \\
\text { administrator; } \\
\text { - ability of sharing (unlimited number of users at the } \\
\text { same time). }\end{array}$ \\
\hline $\begin{array}{l}\text { System } \\
\text { requirements }\end{array}$ & $\begin{array}{l}\text { - Access from PC: } \\
\text { - sound card, speakers and/or headphones; } \\
\text { - RAM } 1 \text { GB or higher; } \\
\text { - Internet connection speed at least } 250 \mathrm{~KB} / \mathrm{s} \text {; } \\
\text { - Access from mobile devices: } \\
\text { - iOs } 5.1 \text { and older and Android } 2.2 \text { and older. }\end{array}$ \\
\hline $\begin{array}{l}\text { User } \\
\text { requirements }\end{array}$ & $\begin{array}{l}\text { - ability to test knowledge; } \\
\text { - posting comments; } \\
\text { - communication with the administrator; } \\
\text { - access from any device. }\end{array}$ \\
\hline
\end{tabular}

Before choosing a platform for the implementation of the project for the organization of online training, it was necessary to determine the method of communication with the target audience. According to surveys conducted at corporate trainings, not all users are comfortable with the option of streaming communication, when the information is provided by the coach in real time and the listener needs to adjust his personal time to the training schedule. Given the trend to personalize their time, the company needs to provide listeners with the possibility of alternatives. Therefore, it was decided to communicate with the client using the following options:

a) Organization of an online training program using Stream technology, that is, in real-time format, when you need to connect to the service at a certain time. This format is convenient if the listener has a desire to communicate with colleagues or with the coach.

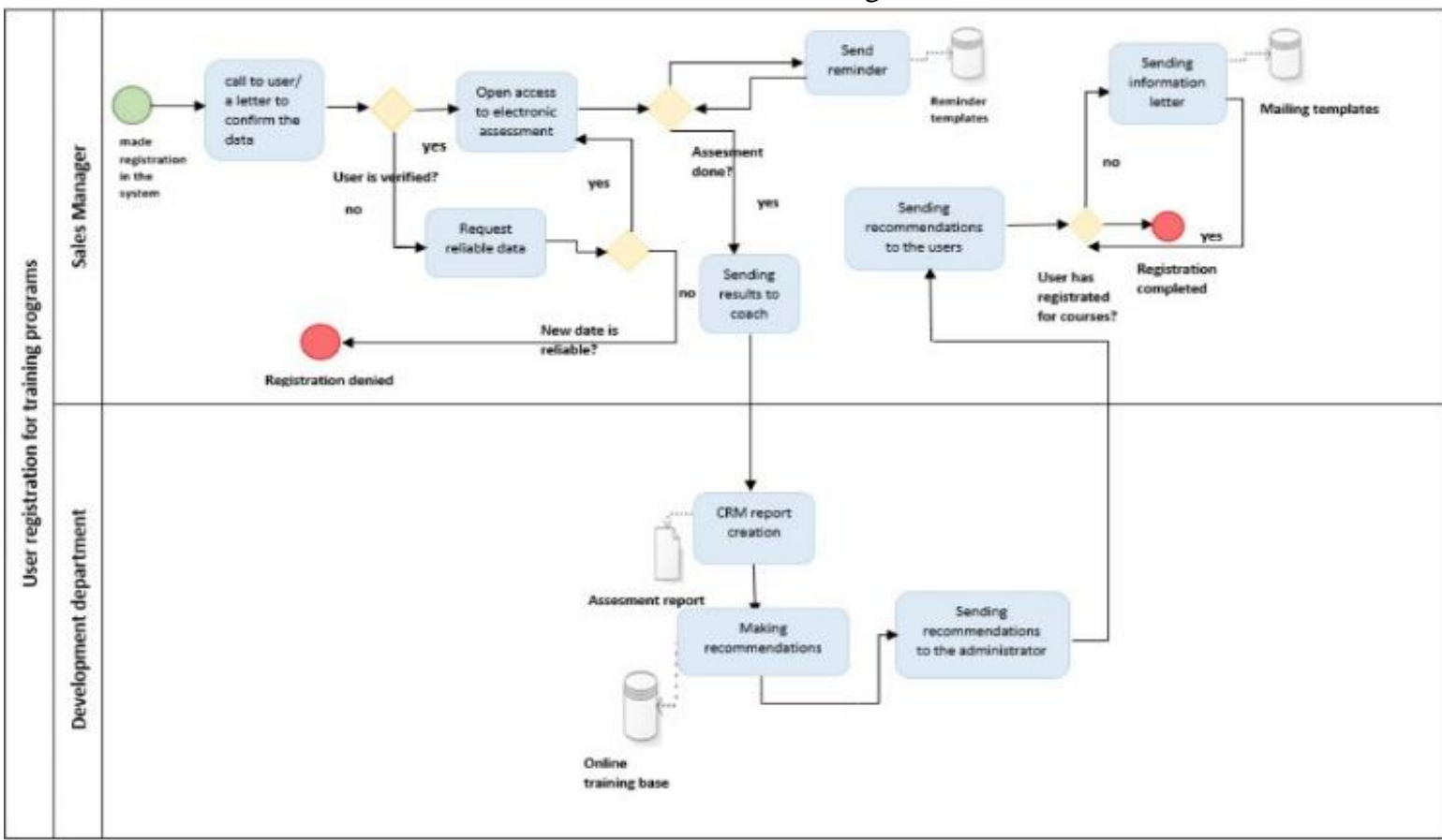

Fig. 3. Process diagram «Registration for training» 
b) Organization of an offline training programme. Placement of training material with the help of cloud services to provide students with the opportunity to plan their training at a time that it will be most comfortable.

The company plans to combine the ability to access knowledge 24/7, conduct webinars and provide access to already recorded training programs. This will provide customers with the most comfortable and effective way of learning.

At the next stage, a comparative analysis of online learning platforms was carried out, the results of which are presented in table 2 [6]. The following parameters were taken into account: functionality, usability, cost of the platform and the level of support. The following technical characteristics were taken into account when choosing:

- ability to bind domain;

- the possibility of distribution and sharding;

- the possibility of holding webinars;

- widget with subscription/sales form;

- the presence of differentiation of access rights;

- interest for receiving payments;

- ability to create a landing page on the service;

- gamification of the learning process.

TABLE II. CHOICE OF ONLINE LEARNING PLATFORM

\begin{tabular}{|l|c|c|c|c|c|}
\hline \multirow{2}{*}{ Platform } & \multicolumn{5}{|c|}{ Number of points } \\
\cline { 2 - 6 } & Item 1 & Item 2 & Item 3 & Item 4 & Total \\
\hline Getcourse & 8 & 7,7 & 2 & 1 & 18,7 \\
\hline Justclick & 7 & 4,5 & 1 & 1 & 13,5 \\
\hline iSpring & 9 & 8,4 & 1 & 3 & 21,4 \\
\hline Etutorium & 8 & 5,2 & 1 & 3 & 17,2 \\
\hline
\end{tabular}

As a result of the analysis, the iSpring platform received the maximum number of points. This service fully meets the needs of the project and, despite the relatively high cost of maintenance, it seems to be the best choice for the company in comparison with the development of its own platform, or using a cheaper and less responsive to the needs of the company analogue.

After selecting the software, the necessary functions were set up for future users, namely:

- interface setting;

- $\quad$ setting up access and roles (administrator, student);

- add training programs;

- loading of educational materials;

- maintaining a calendar plan;

- debugging workspace for webinars;

- setting synchronization with Excel.
Further, the product was tested, in which a focus group of students and an additional 3 administrators took part (business trainer, marketing specialist and analyst). Table 3 presents the results of the testing.

TABLE III. TEST RESULTS

\begin{tabular}{|c|c|}
\hline Name of characteristic & Average score \\
\hline Simplicity of the interface & 4,65 \\
\hline Usability & 4,6 \\
\hline Material loading speed & 3,5 \\
\hline Portal loading speed & 3,4 \\
\hline Ease of communication & 3,8 \\
\hline Video broadcast resolution & 4 \\
\hline Degree of involvement & 4,1 \\
\hline Adaptability to different devices & 4,7 \\
\hline
\end{tabular}

Further, the score was estimated as follows: less than 3.5 - significant changes are required; from 3.6 to 4 - refinement of the average scale; more than 4.1 - minor adjustments.

According to the results of testing, the following activities were carried out: "profile filling" is automatically added to the task list; video materials are compressed to $720 \mathrm{p}$ resolution and exported to a more economical format; notification systems for coaches and participants about new messages are configured; an additional session with the technical support service about possible ways to speed up the work of the site; instructions for users for the best work of the site in case of existing failures are developed; the resulting product is transferred to the operation stage.

The operational period includes work on the content of the platform and the degree of saturation of the trainings conducted on its basis. In addition, debugged technical support and control over the health of the system. During operation, the shortcomings of the system identified during testing were corrected, as well as some aspects of training were improved:

- completely streamlined process of communication between students and trainers;

- added interactive tools: tests, deadlines for tasks, as well as assessment of tasks by coaches with subsequent feedback;

- describes the business processes to speed up technical support and user registration.

To assess the economic efficiency of the project, the capital and operating costs that are necessary for the implementation of online learning platform were calculated [1]. When calculating the performance indicators, it was revealed that the payback period of the project is less than six months, and each ruble invested in the implementation will bring about 8 rubles of additional profit per year. According to the data provided within the reporting period, in just 1 month of operation of the product, without the use of marketing tools, the attendance of the company's website increased by $32 \%$ compared to the average for the previous year. According to the results of the analysis and calculations, 
we can say that the introduction of e-learning program is the right strategic decision on the part of the company.

\section{DISCUSSION}

The concept of training training in recent years has received increasing attention from educational organizations. Despite the fact that the methodological aspects of this form of training are widely covered in the literature, but the problems associated with the mechanism of implementation of online learning platforms in the educational process of training companies are not sufficiently developed. The concept of "business training" appeared several decades ago. The time of active economic development gave rise to the need to find new ways of business development. Along with the traditional ways of optimizing production processes, such as the introduction of process management methods, automation and robotization, various educational methods began to actively develop. But as practice has shown, traditional ways of learning were either too long in time or ineffective.

One of the first theorists and practitioners who started using trainings was Dale Carnegie. He founded «Dale Carnegie Training». It was a training center for the development of self-confidence, public speaking skills, interaction between people and effective communication. The effectiveness of this form of education was much higher than that of conventional forms of traditional education [4].

An important stage in the development of this type of education was the development in the 1970s at the University of Leipzig and Jena, under the guidance of M. Forverg, a method called socio-psychological training. A distinctive feature of this approach was that the tools used in the training increasingly began to be role-playing games with elements of theatrical dramatization that created the conditions for the development of effective skills in self-development, development of communication skills, and management skills. From that moment began the wide practical application of the methods of socio-psychological training of industrial production managers developed by M. Forverg.

Based on the methods developed, in the second half of the 20th century, a new model of training "business training" appeared and began to be actively applied, implying a systematic approach. It allowed to develop simultaneously knowledge, skills and abilities necessary for productive existence of business as a whole, instead of separate process. In contrast to corporate trainings, open trainings were based on sales to a wide range of consumers, in the vast majority of individuals. Such trainings were characterized by the fact that the audience was different both in the status of participants and in the level of initial training [12].

In Russia, the market of training services began to form in the 90 s of the last century. The formation of market methods of economic management has led to the need to develop competencies that were previously not in demand. At this time, neuro-linguistic programming became widespread [3]. Since then, it has become possible to talk about the stable and active development of the training market in Russia.

Digital education is one of the fastest growing segments of the global education market. Projects created on the basis of new technological grounds are called "EdTech". The growth of the market is supported by digitalization of foreign language learning, test preparation, development of the corporate market of online learning. There is a growing need for lifelong learning models that allow for the continued pretraining of staff in accordance with the changing range of tasks.

The following technological trends can be noted: mobile learning and cross-platform are becoming requirements for any learning platform; wearable devices will play a big role in learning; Big Data is needed to improve learning technologies. The following methodological trends can be traced: convergence of recruitment and training; serious Games or gamification in the B2B segment; training in the form of a game; training through observation and copying $[8,15]$.

Advanced training courses, corporate training, advanced training programs in Russian and foreign universities (online and offline), mass online courses (Coursera, edX, etc.), seminars, trainings and internships are included in the additional professional education. According to the Agency DISCOVERY Research Group, the share of the segment "corporate training" is $39 \%$ of the DPO market, and the share of online training is estimated at about $10 \%$ of the total audience [2].

Table 4 presents the dynamics of the ranking of the best training companies in Russia, which have established themselves in the training services market as reliable and progressive companies specializing in corporate business training and have received recognition from customers for good results. The rating is based on a key indicator - customer satisfaction with training, content, form of implementation, competence of a business coach.

TABLE IV. DYNAMICS OF RANKING OF THE LEADING TRAINING COMPANIES IN RUSSIA FOR 2018-2019 YEAR [9]

\begin{tabular}{|l|c|c|}
\hline \multicolumn{1}{|c|}{ Training company } & Rating 2018 & Rating 2019 \\
\hline FinKot & 80 & $65 \downarrow$ \\
\hline $\begin{array}{l}\text { Russkaya Shkola } \\
\text { Upravleniya }\end{array}$ & 40 & $70 \uparrow$ \\
\hline $\begin{array}{l}\text { Biznes-Trening i } \\
\text { konsalting }\end{array}$ & 34 & $26 \downarrow$ \\
\hline ITC Group & 17 & $32 \uparrow$ \\
\hline $\begin{array}{l}\text { Biznes aspekt. Training } \\
\text { center. }\end{array}$ & 16 & $20 \uparrow$ \\
\hline $\begin{array}{l}\text { Biznes Art. Training } \\
\text { center. }\end{array}$ & 14 & $11 \downarrow$ \\
\hline $\begin{array}{l}\text { Profi-kar'era. Center of } \\
\text { professional } \\
\text { development. }\end{array}$ & 11 & $12 \uparrow$ \\
\hline $\begin{array}{l}\text { RFOP Economics and } \\
\text { management }\end{array}$ & 13 & \\
\hline
\end{tabular}

Analysis of the training services market revealed the following main trends:

- growth in the number of corporate training centers;

- use of e-learning systems;

- decrease in the average check for a unique solution;

- games any educational material;

- study the experience of others for use in their work;

- multitasking training [13]. 


\section{CONCLUSIONS}

The study showed that the use of e-learning systems in the educational process at this stage is one of the main trends. The presented method allows to solve the problem of economically and organizationally reasonable implementation of the online learning platform in the training company. The choice of a specific platform should be made taking into account the features of educational programs implemented by the organization and the functional requirements for the information system. The practical result of this work is an implemented functioning platform, which is a ready-made solution from iSpring, which is further promoted through various channels using Internet marketing tools. Using online training will allow training companies to enter new market segments without significantly increasing costs. The results of the study can be used by educational organizations in making decisions about the use of e-learning systems.

This paper was financially supported by the Ministry of Education and Science of the Russian Federation on the programm to improve the competitiveness of Peter the Great St.Petersburg Polytechnic University (SPbPU) among the world's leading research and education centres in the 20162020.

\section{REFERENCES}

[1] Ilin, I., Kalinina, O., Barykin, S. Financial logistics innovations in IT Project Management (2018) MATEC Web of Conferences, 193, 05062 .

[2] A.V. Bataev, Evaluation the e-learning market in Russia (2017) Proceedings of the 2017 International Conference "Quality Management, Transport and Information Security, Information Technologies", IT and QM and IS 2017, № 8085903, pp. 628-633.

[3] D. Friedman, NeoAnalytics. Russian market of distance learning. Moscow: RBC, 2017, 68 p.
[4] P. B. Gavrilov, Trends in the development of online education, MARKETING.SPB.RU: Portal about marketing, 2017: https://www.marketing.spb.ru/mr/education/Online_education.htm

[5] V.V. Glukhov, N.O.Vasetskaya, Improving the teaching quality with a smart-education system (2018) Proceedings of 2017 IEEE 6th Forum Strategic Partnership of Universities and Enterprises of Hi-Tech Branches. pp. 17-21.

[6] I.V. Ilin, A.V. Izotov, S.V. Shirokova, O.V. Rostova, A.I. Levina, Method of decision making support for it market analysis (2017) Proceedings of 2017 20th IEEE International Conference on Soft Computing and Measurements, SCM 2017, № 7970732, pp. 812-814.

[7] S.V. Kalmykova, P.N. Pustylnik, E.M.Razinkina, Role scientometric researches' results in management of forming the educational trajectories in the electronic educational environment (2017) Advances in Intelligent Systems and Computing, pp. 427- 432.

[8] D. Konanchuk, The Greenfield era in education. Moscow: SKOLKOVO business school, 2013, 52 p.

[9] V. Krasulina, Rating training companies. B-SEMINAR.RU: Portal of business education, 2018: https://www.b-seminar.ru/rating/company/

[10] S.V. Krasnov, S.V.Kalmykova, E.E. Abushova, A.S. Krasnov, Problems of Quality of Education in the Implementation of Online Courses in the Educational Process (2018) International Conference on High Technology for Sustainable Development, HiTech 2018 Proceedings, № 8566618 .

[11] D. Miroshnichenko, Online education market review, OPENBUSINESS.RU: Portal of business plans and guidelines for opening a small business, 2017: https://www.openbusiness.ru.obzorrynka-onlayn-obrazovaniya/

[12] N.V.Rebrikova, O.V. Kolesnikova, Research of the educational services market, Molodoy ucheniy, 2017, 14 (148), pp. 417- 420.

[13] Research of the Russian market of online education, EDUMARKET.DIGITAL: portal about research of the Russian market of online education. 2018: https://edmarket.digital/

[14] Rostova, O., Shirokova, S., Shmeleva, A. Resultative approach to distribution of budget resources of municipalities (2018) MATEC Web of Conferences, 170, № 01024.

[15] V.N. Volkova, A.V.Loginova, S.V.Shirokova, E.A. Iakovleva, Models for the study of the priorities of innovative companies (2016) Proceedings of the 19th International Conference on Soft Computing and Measurements, SCM 2016, № 7519831, pp. 515-517. 